\title{
Editorial
}

\section{O ponto de partida}

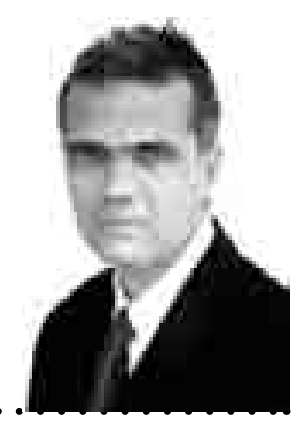

Marco Antonio Guimarães da Silva,Med.Dr.Sci.

marco@atlanticaedu.com.br

Ha alguns dias, o editor executivo da Fisioterapia Brasil e eu conversávamos sobre alguns artigos que, ainda que amparados em excelentes idéias, não foram aceitos para publicação, por apresentarem duvidosas evidências em seus resultados

Como ex-professor de disciplina, no stricto sensu, ligada à evidência cientifica e trabalhando com pesquisa desde 1975, tenho sido um critico fervoroso às investigaçóes cientificas cujos achados devem ser interpretados com muita cautela, tamanha a quantidade de vieses presentes.

O tema da conversa - rejeição de artigos - me fez refletir sobre o assunto e buscar uma alternativa, para náo sepultar a idéia que o autor não soube, ao executar e publicar o seu trabalho, desenvolver segundo as convençóes e normas cientificas impostas pela comunidade acadêmica.

Como fazer digressão tem sido o meu forte, farei uma leitura tendenciosa e circunstanciada da seguinte colocaçáo feita por Santo Agostinho: "O ponto de partida para a verdade não está na razão, mas sim na fé que precede essa razão". Observando-se que os fatores extrínsecos e intrínsecos, relacionados à investigação, não constituirão impeditivos à execução do trabalho eu diria, em substituição ao que nos disse o teólogo - filósofo: o ponto de partida não está na perfeita execução do trabalho, mas antes na originalidade e simplicidade da idéia e tema que precedem essa execução!

Sabemos, todos os que trabalhamos na orientação de alunos de doutorado, das dificuldades que esses alunos encontram para a escolha do seu tema. Não fosse a intervençáo do orientador, muitos teriam desistido, ou seja: ter uma boa idéia para um trabalho científico nem sempre é muito fácil! Seria justo abortar a publicação de um trabalho que encerra uma idéia interessante, mas não atende às evidências impostas pelo mundo acadêmico? Por outro lado, é justo publicar um trabalho com uma concepçáo criativa medíocre, mas que atende às citadas normas?
A ciência quantitativa submete as suas comprovaçôes a testes de hipóteses e se ampara fundamentalmente nas relaçóes de causalidade. Uma causalidade que serve para estabelecer uma correlação e para registrar acontecimentos aparentemente desconexos em um enredo de prospecção e retrospecção temporal.

O conhecimento científico tem que ter relação com regras de comunidades científicas que não admitem equívocos, ou com um sistema que admita possibilidade da produçáo de erros e de sua superação? Os erros aqui descritos não se contextualizam dentro dos níveis de significância que estabelecemos no trabalho cientifico; são conceitualmente os erros tidos como vieses e que podem comprometer as relaçóes de causalidade. O problema maior reside no fato de que se o trabalho enviado para a publicação não apresentar as tais evidências ele é rechaçado. O que fazer?

Talvez buscar inspiração em Popper (Conjecturas e Refutaçóes) e deixar de lado a atitude dogmática e limitadora de só aceitar como leis aquelas que foram verificadas, e consentir, provisoriamente, o que ainda não foi comprovado. Não considerar que o erro seja um defeito, mas um momento necessário do desenvolvimento do trabalho.

Há alguns anos, participei de um encontro na UFSCar que reuniu os editores científicos das revistas de fisioterapia. Sugeri, nesse encontro, que houvesse uma avaliaçáo critica ao final de cada artigo publicado. A análise que então propusera exporia os principais "erros" encontrados no trabalho e as sugestôes, para que efetivamente as relaçôes causais pudessem ser evidenciadas de fato.

A sugestão não prosperou, mas talvez seja a hora de ressuscitá-la e dar oportunidade para àqueles que, longe do seio acadêmico, possam, ainda que com erros e imperfeiçôes, trazer as suas contribuiçóes. 